\title{
Home range size, habitat use and nesting success of Swamp Francolin Francolinus gularis on agricultural land in northern India
}

PERWEZ IQUBAL, PHILIP J.K. MCGOWAN, JOHN P. CARROLL and ASAD R. RAHMANI

\begin{abstract}
Summary
Swamp Francolin Francolinus gularis is considered Vulnerable to extinction as its native grassland habitat is converted to agricultural land. However, there are virtually no life history data available to allow the impact of these changes on the species to be assessed. Thirteen birds were radio-tracked during the breeding season on agricultural land near Dudwa National Park in Uttar Pradesh, northern India. The study area was dominated by sugar-cane fields, but also contained other crops and natural wet grassland. Home range size varied from $273 \mathrm{~m}^{2}$ to $2,687 \mathrm{~m}^{2}$ and was significantly correlated with tracking duration. We did not detect significant patterns in overall use of habitats at either the home-range level $(P=0.14)$ or at the radio-location level $(P=0.13)$. However, some individual habitats appeared to be used in proportions that differed from random expectations. At the home range level, birds appeared to favour tall sugar-cane and grassland whilst at the individual location level, grassland and wet areas were most used. Radio-tagged birds made six nests, of which only two hatched young. One was in an old sugar-cane field and the other on grassland. Although we did not detect statistical significance, we believe that developing an appropriate management regime for this species is so urgent that the results are sufficient to manage adaptively the species' habitat at least on an experimental scale. These data suggest that a matrix of habitats, including agricultural land, can supply the necessary components to satisfy the various requirements of Swamp Francolin. However, some natural grassland habitat associated with wet areas appears to be critical. The crucial challenge is to make sure that agricultural landscapes have these habitats present in the right proportions and spatial arrangements to support viable populations of Swamp Francolin.
\end{abstract}

\section{Introduction}

Swamp Francolin Francolinus gularis is considered Vulnerable to extinction because of drainage and conversion to agriculture of its wet grassland habitat in northern India (McGowan et al. 1995, BirdLife International 2000, Fuller et al. 2000, Hilton-Taylor, 2000). Its distribution is limited to the low-lying terai belt that lies between the Himalayan foothills to the north and the Indo-Gangetic plains to the south (Ali and Ripley 1983). This belt runs along the Indo-Nepalese border eastwards to the north-east Indian state of Assam and is characterized by 
Sal Shorea robusta forests and large expanses of wet grassland (see Anon. 1990 and Rahmani et al. 1991 for further information on the vegetation of the terai). Much of the forest in the terai has now been felled and the grasslands are being replaced with sugar-cane fields.

Swamp Francolin typically inhabits swampy areas around seasonal marshes (taals), which lie in the flood-plains of major rivers. It is not known how the species is faring in this much-changed landscape, but it is assumed that its habitat has become reduced and fragmented. Despite this, recent surveys have identified populations in both India (McGowan et al. 1996, Javed et al. 1999) and Nepal (Dahal 2001, Shakya et al. 2001, see also Kalsi et al. 2001). A particular concern is whether this species is able to survive in the now extensive sugar-cane fields that surround the marshy areas that they still inhabit. If the species can use these fields and breed successfully, then its chances of survival may be far better than is currently thought. If, however, they cannot, then there should be considerable cause for concern, as sugar-cane farming is continuing to dominate much of this region. The sugar-cane is harvested during the Swamp Francolin's breeding season, adding further uncertainty to its value for the species.

As there is no reliable information upon which to predict the likely survival of increasingly isolated Swamp Francolin populations, we set out to determine the size of individual home ranges and habitat use during the breeding period, as well as nesting success.

\section{Study area}

The study was conducted around Ghola Taal (i.e. marsh), which lies just outside Dudwa National Park in Uttar Pradesh, northern India (Figure 1). Specifically, land lying along the southern and south-eastern edges of the taal, closest to the village was used (see McGowan et al. 1996). The taal had limited open water, which was surrounded by marshy vegetation, grassland and fields of sugar-cane and other crops, such as pulses, mustard, rice and vegetables. The area is inundated for four to five months during and after the monsoon each year. Seven habitat categories were used in this study:

i), ii) Sugar-cane covers much of the study area, mostly as tall crops (3 $\mathrm{m}$ or more), which were mature and ready for harvest, but also as younger crops including recently planted stems. To allow for this considerable variation, two size classes were used: "short" (less than $150 \mathrm{~cm}$ tall) and "tall" (greater than $150 \mathrm{~cm}$ tall).

iii) Old sugar-cane fields were those that had previously been used for growing this crop but were not currently in use. They were dominated by stems of uncultivated sugar-cane and wet grasses such as Phragmites karka, Arundo donax and Saccharum spp. Typically this vegetation reached $100-200 \mathrm{~cm}$ in height.

iv) Other crops that were cultivated included pulses, mustard, rice and vegetables.

v) Seasonal waterbodies were present either as standing water (e.g. in open areas of the taal itself), or in channels and streams.

vi) Marshes next to these waterbodies were characterized by the sedges Typha angustifolia and Cyperus rotundus. 


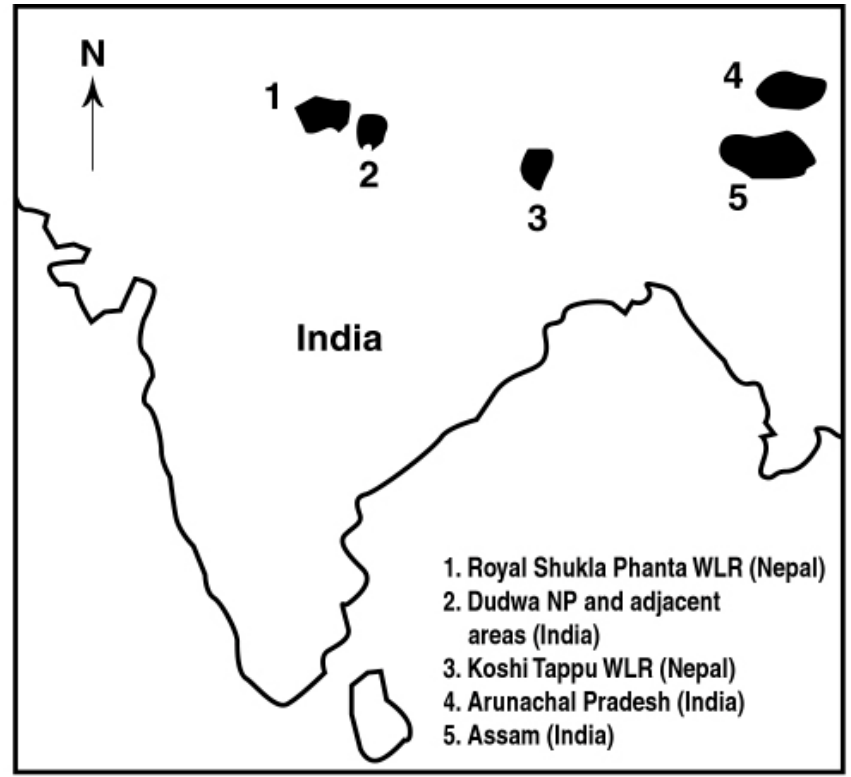

Figure 1. Known distribution of Swamp Francolin in northern India and southern Nepal. The location of Dudwa National Park is shown (from Kalsi et al. 2001).

vii) Grassland areas around the taal were dominated by Saccharum spontaneum, which was 100-300 cm tall. Other grass species present included Saccharum munja, Phragmites karka, Arundo donax and Vetiveria zizaniodes.

Much of the native grassland habitat in this area has been converted to sugarcane agriculture. During the study, $42 \%$ of the study area was covered in tall sugar-cane, old sugar-cane made up $19 \%$ of the area, and short sugar-cane comprised $4 \%$ of the area. However, these are rather ephemeral habitats and changed in availability during the study (February-June) as tall sugar-cane was harvested and replaced with short stems planted to produce the following year's crop. Grasslands comprised $22 \%$ of the study area; seasonal water, marshes and other crops each covered $4 \%$ (see Figure 2).

\section{Methods}

There are practical difficulties in assessing Swamp Francolin's response to landuse change. These include its secretive nature and the tall dense grassland that it inhabits, both of which make the species difficult to detect. Furthermore, its natural habitat is now mostly confined to protected areas that include tiger Panthera tigris and/or rhinoceros Rhinoceros unicornis and so moving about on foot can be unwise. McGowan et al. (1996) found that dawn and dusk call counts detected more birds at a site than visits at other times of the day and they identified a site where an intensive study of habitat use on agricultural land was practical. In order to study habitat use in detail, however, the movements of individuals must be sampled without disturbing them and this requires the 


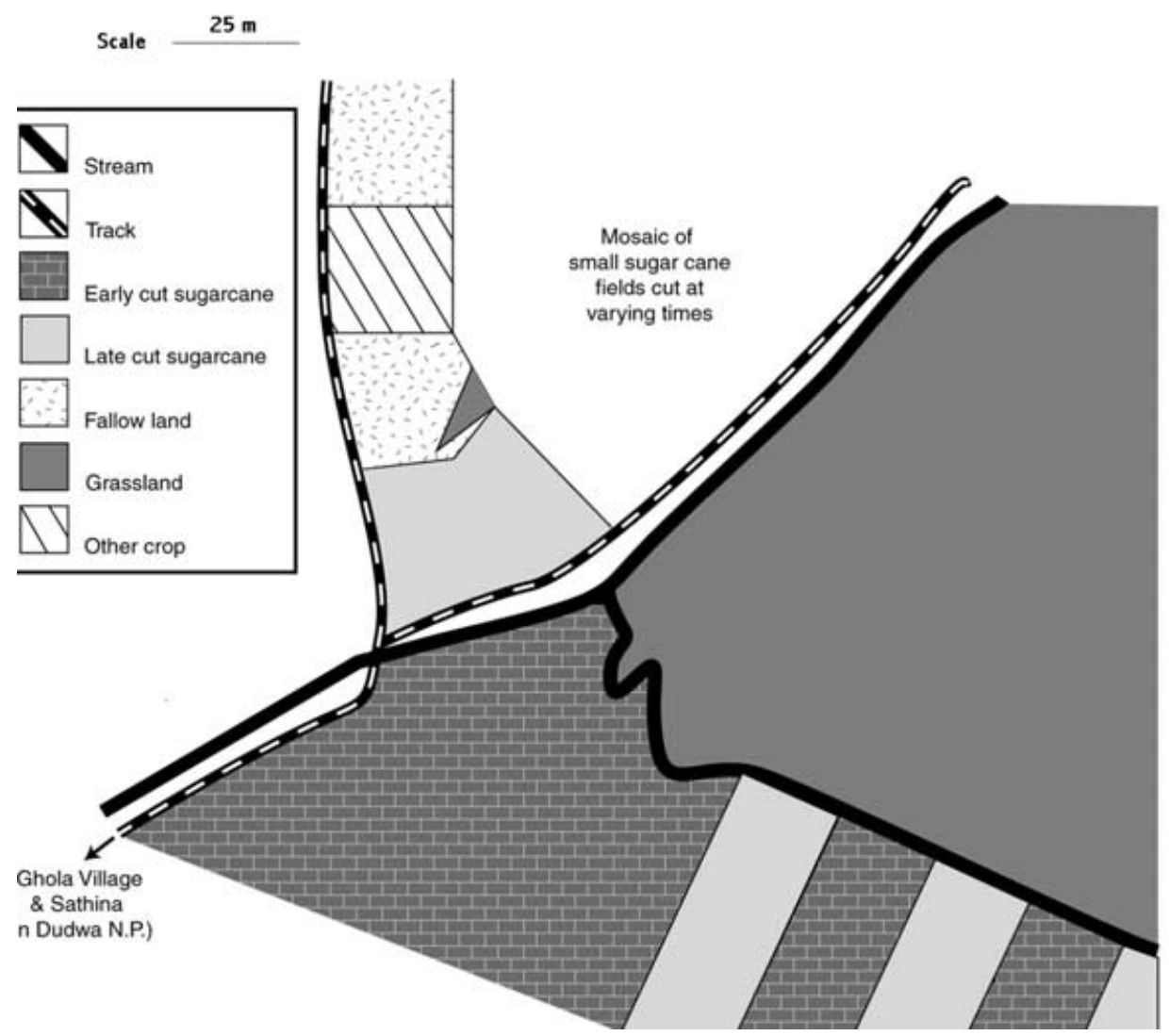

Figure 2. Sketch of study area and habitats in Ghola Taal outside Dudwa National Park, Uttar Pradesh, India.

attachment of radio-tags and subsequent tracking. The boundaries of the study area were defined by the radio-tagged birds.

\section{Trapping and radio-tracking}

Birds were trapped between February and early April 1998 by driving them into mist-nets. A line of mist-nets was erected at one end of a sugar-cane field that was then driven from the other end. This was done slowly along most of the length of the field and rapidly towards the end so that any birds would be flushed into the nets. Each trapped individual was fitted with a necklace transmitter that weighed less than $2 \%$ of body weight.

Tagged birds were located once each day from the date of capture until the onset of the monsoon on 25 June or until loss or death. Individuals were located at randomly selected times each day between o6hoo and 21hoo. Their positions were located by triangulating from at least three points that were marked on a map of the study area. Transmitter ranges were typically less than $250 \mathrm{~m}$, and 
so birds were routinely approached very closely so that each location could be reliably assigned to a patch of habitat. Triangulation errors were therefore small. Minimum convex polygon ranges were then calculated for each tagged bird.

\section{Habitat use}

A habitat map of the area used by all of the radio-tagged birds was prepared by plotting the size and shape of each field and patch of natural vegetation. Compositional analysis was used to compare the birds' use of the habitats present with their availability. This technique assesses whether habitats are used in the same proportions as they occur. The analysis was done at two levels (Aebischer et al. 1993). First the proportion of each habitat in the study area was compared with that found in the convex polygon home range of each radiotagged individual. Second, the proportion of each habitat within each home range was compared with the proportion of radio-locations in that habitat. MacComp 0.90 (J.P. Carroll unpubl. package) was used to determine use of all habitats simultaneously using multivariate analysis of variance (MANOVA). Paired comparisons of all habitats were then carried out using $t$-tests to obtain a ranking matrix (Aebischer et al. 1993). These were then used to generate a rank order that described how the habitats were used compared with their availability.

\section{Nesting}

For any radio-tagged pair that built a nest, the habitat in which it was located was recorded. Clutch size was also noted and nest success monitored. Specific attempts were made to encounter broods so that the number of chicks could be counted. This was done by waiting for chicks to emerge into open areas when radio-tracking indicated that birds were in or near habitats where sightings would be possible.

\section{Results}

Thirteen birds in adult plumage were radio-tagged. One female was predated within three days and so was not used in any analyses. Of the remaining 12, five were males and seven were females and they were tracked for between 36 and 130 days (Table 1 ). Two further females were lost during radio-tracking (see Table 3), leaving to birds tracked from capture until the onset of the monsoon.

\section{Home range size}

Range size was significantly correlated with duration of radio-tracking $(r=0.727$, $P=0.008$; Figure 3). There was no significant difference in the number of days tracked between males and females (Mann-Whitney $U=10.0, P=0.22)$. Mean range size was $1,050 \mathrm{~m}^{2}(n=12, \mathrm{SE}=209.88)$. Male home ranges $(n=5$, mean $=$ $\left.1,396 \mathrm{~m}^{2}, \mathrm{SE}=418.13\right)$ averaged larger than female's $\left(n=7\right.$, mean $=822 \mathrm{~m}^{2}, \mathrm{SE}=$ 185.51; Table 1), although this difference was not significant (Mann-Whitney $U=$ 10.5, $P=0.26$ ).

It is striking that the mean range size is very small indeed and comparison of 
Table 1. Home range sizes of radio-tagged Swamp Francolins in Ghola Taal, near Dudwa National Park, northern India.

\begin{tabular}{|c|c|c|c|c|c|c|c|}
\hline \multicolumn{4}{|c|}{ Male } & \multicolumn{4}{|c|}{ Female } \\
\hline Bird & $\begin{array}{l}\text { Date } \\
\text { trapped }\end{array}$ & $\begin{array}{l}\text { Days } \\
\text { tracked }\end{array}$ & $\begin{array}{l}\text { Home } \\
\text { range } \\
\left(\mathrm{m}^{2}\right)\end{array}$ & Bird & $\begin{array}{l}\text { Date } \\
\text { trapped }\end{array}$ & $\begin{array}{l}\text { Days } \\
\text { tracked }\end{array}$ & $\begin{array}{l}\text { Home } \\
\text { range } \\
\left(\mathrm{m}^{2}\right)\end{array}$ \\
\hline $\mathrm{M}_{1}$ & $13 \mathrm{Feb}$ & 130 & 604 & $\mathrm{~F}_{1}^{*}$ & $13 \mathrm{Feb}$ & 130 & 1,634 \\
\hline $\mathrm{M}^{*}$ * & 4 Mar & 106 & 2,024 & $\mathrm{~F}_{2}$ & $9 \mathrm{Apr}$ & 73 & 852 \\
\hline $\mathrm{M}_{3}$ & 9 Apr & 73 & 852 & $F_{3}$ & $7 \mathrm{Apr}$ & 75 & 828 \\
\hline $\mathrm{M}_{4}^{*}$ & $21 \mathrm{Feb}$ & 63 & 679 & $\mathrm{~F}_{4}$ & $26 \mathrm{Mar}$ & 88 & 1,272 \\
\hline \multirow[t]{3}{*}{$\mathrm{M}_{5}$} & $13 \mathrm{Feb}$ & 127 & 2,687 & $\mathrm{~F}_{5}^{*}$ & $20 \mathrm{Feb}$ & 49 & 460 \\
\hline & & & & F6 & $30 \mathrm{Mar}$ & 36 & 273 \\
\hline & & & & $\mathrm{F}_{7}$ & $8 \mathrm{Apr}$ & 39 & 436 \\
\hline
\end{tabular}

* Denotes non-nesting birds. $\mathrm{M}_{3}$ and $\mathrm{F}_{2}$ formed a pair and were trapped at the same time, and $\mathrm{M}_{5}$ and $\mathrm{F}_{7}$ also formed a pair but were trapped at different times. The success or reason for failure of nesting birds is given in Table 3. As one location was taken each day for each radio-tagged bird, the number of days also corresponds to the number of radio-locations used in the analysis.

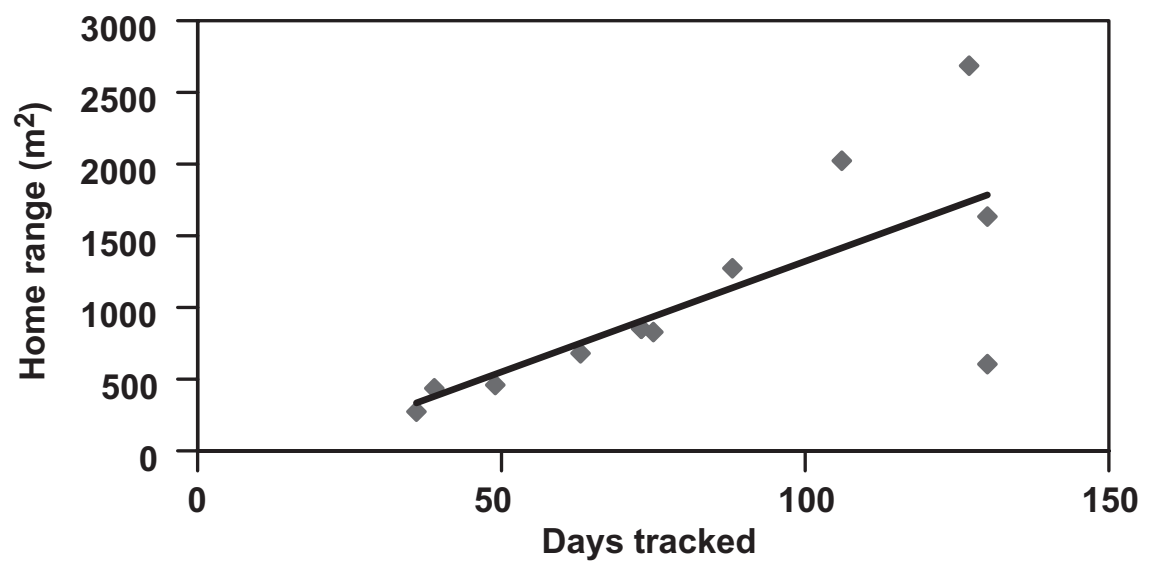

Figure 3. Correlation ( $r=0.727, P=0.008)$ between home range size and number of days tracked for 12 radio-tagged Swamp Francolin. One pair ( $\mathrm{M}_{3}$ and $\mathrm{F}_{2}$ ) moved together throughout the study and thus used the same area (see Table 1).

Tables 1 and 3 indicate that nesting may influence home range size. The two smallest range sizes were those of females that were killed on the nest (F6 and $\mathrm{F}_{7}$ ). In contrast the four largest range sizes were birds that either were not taking part in nesting or which were disturbed during nesting $\left(\mathrm{M}_{2}, \mathrm{M}_{5}, \mathrm{~F}_{1}\right.$ and $\left.\mathrm{F}_{4}\right)$. For example, $\mathrm{M}_{5}$ was paired with $\mathrm{F}_{7}$, which was trapped on the nest by poachers. The female's range size was amongst the smallest recorded and the male's was the largest.

\section{Habitat use}

Our radio-telemetry data on habitat use failed to detect significant patterns in the overall use and availability of habitats at both the study area-home range 
level (Wilks' $\lambda=0.22, P=0.14$ ) and the home range-individual location level $(\lambda=$ $0.25, P=0.13)$. Inspection of the matrices did, however, reveal some significant relationships at both levels (Table 2A, B). At the study area-home range level, there was a significant preference for tall sugar-cane when compared with both marsh areas and short sugar-cane and the preference for tall sugar-cane over waterbodies approached formal significance $(P=0.068)$. At the home range-individual location level, however, grassland was preferred significantly over both tall sugar-cane and other crops.

Overall, both tall sugar-cane and grassland appeared to be the most favoured habitats at the study area-home range level (i.e. rank values of 1 and 2 in Table $2 \mathrm{~A}$ ), with waterbodies and marsh least favoured (i.e. rank values of 6 and 7 in Table $2 \mathrm{~A}$ ). At the home range-radio-location level seasonal waterbodies and grassland appeared to be most favoured (i.e. rank values of 1 and 2 in Table $2 B$ ) and marsh and short sugar-cane the least preferred (i.e. rank values of 6 and 7 in Table $2 \mathrm{~B}$ ).

\section{Nesting success}

Eight of the 12 radio-tagged birds took part in breeding in six pairs (Table 3 ) and all six nests were found. Mean clutch size was 5.4 (range $4-7 ; n=5$ ), and only two pairs completed incubation successfully. One nest was made in a sugar-cane field and was lost when the cane was harvested. Two other nesting females were caught, one by a village dog and one by poachers (Table 3 ).

\section{Discussion}

The range sizes recorded during this study were remarkably small. Birds involved in nesting and the early stages of chick-rearing appeared to range over a very limited area. In contrast, the largest range sizes observed, which were still small compared with other Galliformes, were those individuals that had either not attempted nesting, or whose attempts had been disturbed. The relationship between the number of days that a bird was radio-tagged and its range size, would, therefore, seem likely to be a consequence of birds moving further once nesting was completed. It is probable, therefore, that this range size would continue to increase for nesting birds. It is less clear whether the range size of nonnesting birds, or those individuals that had their nesting disrupted would continue to increase.

During the calling and nesting period, Swamp Francolins that were radiotracked in this study appeared to be using some habitats in different proportions to those in which they were available. However, the relationships were not significant. This may have been due to at least four factors. First, the sample size here was small, so that only the largest of differences would have been detected and any more subtle effects would not be shown. There was considerable variation among individuals in the use of habitats and so it is all the more difficult to detect anything other than large differences within our small sample size. Second, the overall study area was defined by the radio-tagged birds. Therefore comparisons of habitat proportions at the study area-home range level were conservative because areas containing no birds (and probably poorer habitat) would not have 
Table 2. Matrix of the proportions of habitat available in the study area compared with those present in Swamp Francolin home ranges (A) and home range proportions compared to radio-locations (B) at Ghola Taal, near Dudwa National Park, northern India.

\begin{tabular}{|c|c|c|c|c|c|c|c|c|}
\hline & & $\begin{array}{l}\text { Tall } \\
\text { sugar- } \\
\text { cane }\end{array}$ & $\begin{array}{l}\text { Grass- } \\
\text { land }\end{array}$ & $\begin{array}{l}\text { Old } \\
\text { sugar- } \\
\text { cane }\end{array}$ & $\begin{array}{l}\text { Water- } \\
\text { bodies }\end{array}$ & Marsh & $\begin{array}{l}\text { Short } \\
\text { sugar- } \\
\text { cane }\end{array}$ & Other \\
\hline \multicolumn{9}{|l|}{ A } \\
\hline Tall sugar-cane & $\begin{array}{l}\mathrm{x} \\
\mathrm{SE} \\
P\end{array}$ & & (n.s.) & (n.s.) & (n.s.) & $\begin{array}{r}-1.7451 \\
0.5854 \\
0.0200\end{array}$ & $\begin{array}{r}-1.9328 \\
0.7405 \\
0.0380\end{array}$ & (n.s.) \\
\hline Grassland & $\begin{array}{l}\mathrm{x} \\
\mathrm{SE} \\
P\end{array}$ & (n.s.) & & (n.s.) & (n.s.) & (n.s.) & (n.s.) & (n.s.) \\
\hline Old sugar-cane & $\begin{array}{l}\mathrm{x} \\
\mathrm{SE} \\
P\end{array}$ & (n.s.) & (n.s.) & & (n.s.) & (n.s.) & (n.s.) & (n.s.) \\
\hline Waterbodies & $\begin{array}{l}\mathrm{x} \\
\mathrm{SE} \\
P\end{array}$ & (n.s.) & (n.s.) & (n.s.) & & (n.s.) & (n.s.) & (n.s.) \\
\hline Marsh & $\begin{array}{l}\mathrm{x} \\
\mathrm{SE} \\
P\end{array}$ & $\begin{array}{l}1.7451 \\
0.5854 \\
0.0200\end{array}$ & (n.s.) & (n.s.) & (n.s.) & & (n.s.) & (n.s.) \\
\hline Short sugar-cane & $\begin{array}{l}\mathrm{x} \\
\mathrm{SE} \\
P\end{array}$ & $\begin{array}{l}1.9328 \\
0.7405 \\
0.0380\end{array}$ & (n.s.) & (n.s.) & (n.s.) & (n.s.) & & (n.s.) \\
\hline Other & $\begin{array}{l}\mathrm{x} \\
\mathrm{SE} \\
P\end{array}$ & (n.s.) & (n.s.) & (n.s.) & (n.s.) & (n.s.) & (n.s.) & \\
\hline Rank & & 1 & 2 & 4 & 6 & 7 & 5 & 3 \\
\hline \multicolumn{9}{|l|}{ B } \\
\hline Tall sugar-cane & $\begin{array}{l}\mathrm{x} \\
\mathrm{SE} \\
P\end{array}$ & & $\begin{array}{l}0.8745 \\
0.3722 \\
0.0400\end{array}$ & (n.s.) & (n.s.) & (n.s.) & (n.s.) & (n.s.) \\
\hline Grassland & $\begin{array}{l}\mathrm{x} \\
\mathrm{SE} \\
P\end{array}$ & $\begin{array}{r}-0.8745 \\
0.3722 \\
0.0400\end{array}$ & & (n.s.) & (n.s.) & (n.s.) & (n.s.) & $\begin{array}{r}-3.2948 \\
1.1477 \\
0.0480\end{array}$ \\
\hline Old sugar-cane & $\begin{array}{l}\mathrm{x} \\
\mathrm{SE} \\
P\end{array}$ & (n.s.) & (n.s.) & & (n.s.) & (n.s.) & (n.s.) & (n.s.) \\
\hline Waterbodies & $\begin{array}{l}x \\
\text { SE } \\
P\end{array}$ & (n.s.) & (n.s.) & (n.s.) & & (n.s.) & (n.s.) & (n.s.) \\
\hline Marsh & $\begin{array}{l}\mathrm{x} \\
\mathrm{SE} \\
P\end{array}$ & (n.s.) & (n.s.) & (n.s.) & (n.s.) & & (n.s.) & (n.s.) \\
\hline Short sugar-cane & $\begin{array}{l}\mathrm{x} \\
\mathrm{SE} \\
P\end{array}$ & (n.s.) & (n.s.) & (n.s.) & (n.s.) & (n.s.) & & (n.s.) \\
\hline Other & $\begin{array}{l}\mathrm{x} \\
\mathrm{SE} \\
P\end{array}$ & (n.s.) & $\begin{array}{l}3.2948 \\
1.1477 \\
0.0480\end{array}$ & (n.s.) & (n.s.) & (n.s.) & (n.s.) & \\
\hline Rank & 4 & 2 & 3 & 1 & 6 & 7 & 5 & \\
\hline
\end{tabular}

$x$, mean logratio differences (negative means indicate that the row habitat was used more than the column habitat and a positive value indicates the opposite); SE, standard error; $P$, probability that differences are obtained by random chance. 
Table 3. Nesting habitat and breeding success of radio-tagged Swamp Francolins at Ghola Taal near Dudwa National Park in northern India.

\begin{tabular}{|c|c|c|c|c|c|}
\hline Male & Female & Habitat & $\begin{array}{l}\text { Clutch } \\
\text { size }\end{array}$ & $\begin{array}{l}\text { No. } \\
\text { hatched }\end{array}$ & Reason for failure* \\
\hline M5 & $\mathrm{F}_{7}$ & Grassland & 7 & o & Female trapped by poachers \\
\hline $\mathrm{M}_{3}$ & $\mathrm{~F}_{2}$ & $\begin{array}{l}\text { Old } \\
\text { sugar-cane }\end{array}$ & 5 & 5 & - \\
\hline Untagged & $\mathrm{F}_{4}$ & $\begin{array}{l}\text { Tall } \\
\text { sugar-cane }\end{array}$ & 5 & o & $\begin{array}{l}\text { Field harvested during } \\
\text { incubation and eggs taken }\end{array}$ \\
\hline Untagged & $\mathrm{F}_{3}$ & $\begin{array}{l}\text { Old } \\
\text { sugar-cane }\end{array}$ & 4 & $\mathrm{o}$ & $\begin{array}{l}\text { Unknown, presumably natural } \\
\text { as incubation was completed }\end{array}$ \\
\hline Untagged & F6 & $\begin{array}{l}\text { Old } \\
\text { sugar-cane }\end{array}$ & 6 & o & $\begin{array}{l}\text { Female preyed upon by } \\
\text { village dog }\end{array}$ \\
\hline Mi & Untagged & Grassland & Not known & 4 & - \\
\hline
\end{tabular}

* Unless noted, all birds survived until the end of tracking on 25 June when the monsoon broke.

been included in this analysis. Third, there may have been no real difference in habitat use, with birds using the habitats in the proportions that they were available, and our results were simply chance. Fourth, the harvesting of sugar-cane during the study period may have masked any preference, especially in the change from tall sugar-cane, which appeared to be an important habitat, to short sugar-cane, which was not.

This last reason is an important consideration as it indicates that our results were conservative: i.e. the harvesting made it difficult to accurately track quantifiable changes in habitat availability and thus detect significant differences in habitat preference. We suggest, however, that there were trends at both levels, which, when combined with our information on nest sites and success, indicated that some habitats were more important than others to Swamp Francolin during the breeding season. At the study area-home range level, home ranges tended to be sited in tall sugar-cane and grassland rather than in the other habitats. The proportion of these in individual home ranges varied considerably, and may suggest that not all home ranges were of equal quality, with better home ranges containing more of a preferred habitat (tall sugar-cane and grassland). Other habitats were less preferred.

At the home range-individual location level, birds tended to associate with seasonal waterbodies and grassland probably because these habitats usually occurred together. Although marshes also tended to be associated with waterbodies and grassland it might be that we were seeing greater use of tall vegetation at the end of the dry season when the waterbodies contained no water. Tall sugar-cane and disused sugar-cane fields may also have been important.

Much of the study area was covered in tall sugar-cane that was harvested by the local farmers during the study period and so became less available to the birds than it was at the start of radio-tracking. This seems likely to have influenced the birds' use of habitats within their home ranges: the proportions of tall sugar-cane in each home range would have decreased and that of short sugarcane increased as the study progressed. This would have led to the replacement of a habitat that was important to Swamp Francolin with one that was used much less, and this trend increased as the breeding season progressed. 
These results suggest that tall sugar-cane and grassland may be important habitats for Swamp Francolin and their presence is necessary in this part of the terai. However, only one of six nests was located in currently used sugar-cane fields (comprising $<40 \%$ of the study area), suggesting that whilst tall sugar-cane is extensively used by Swamp Francolin, it does not appear to be used much for nesting and we speculate, therefore, that its benefit to recruitment into the population would be limited to use for chick-rearing cover, if at all. Although unused sugar-cane fields comprised only $20 \%$ of the study area, three of the six nests were found in this habitat. Altogether, this indicates that unused sugar-cane fields close to currently used sugar-cane fields may be important for Swamp Francolin. Therefore, a matrix of habitats, including tall crop fields and native grassland, is likely to be necessary during the breeding season.

The study period covered four-and-a-half months and it took nearly two months to trap 12 birds. Given the variability between individuals in habitat use, our results indicate that larger sample sizes may be required to describe fully habitat use during this period. Therefore, it was not possible to subdivide the study period into shorter periods that would allow habitat use and availability to be quantified on a finer time scale.

Although we have not detected statistically unequivocal evidence of an overall selection of some habitat types, we believe that there is sufficient indication that some habitats are being preferred to justify using these results to initiate a planned programme of adaptive management (see Walters 1986, Salafsky et al. 2001). Adaptive management is simply the incorporation of research into conservation action such that design, management and monitoring is used to test systematically assumptions in order to adapt and learn (Salafsky et al. 2001). This is appropriate in this case, because we urgently need to find out which habitat management regimes are most likely to ensure that individual, isolated Swamp Francolin populations do not become extinct. The results suggest that this process should start by ensuring that patches of tall native grassland remain within the sugar-cane matrix. Farmers could be encouraged to leave patches of native grassland between sugar-cane fields. Leaving some sugar-cane fields out of production periodically would add further nesting cover to the habitat mosaic on agricultural land.

The results from habitat analysis at two levels, and the siting of nests, indicated that the habitats present were used for different activities. Therefore, there is a need to ensure that the habitats are available in suitable proportions and are arranged appropriately with respect to each other and at a spatial scale appropriate to the range sizes of individuals. For example, whilst tall sugar-cane fields may be important, the evidence presented here suggests that they are unlikely to support successful nests. Add to this the dynamism of habitat availability as the sugar-cane is harvested and there is clearly a challenge to ensure that the matrix present at any time meets all of the needs of Swamp Francolin.

There is clearly a need to understand the dynamics of Swamp Francolin populations in both agricultural land and natural habitats. This will determine the extent to which man-made habitats are adequate or necessary for some parts of the Swamp Francolin's life history, or will indicate that they are simply a sink for populations from natural habitats. In Ghola Taal, the wet grasslands in adjacent areas of Dudwa National Park could be the sources for such birds. 


\section{Acknowledgements}

This project resulted from an Indian Universities Grant Commission-British Council link and we are grateful to Dr Peter Garson and Professor Abbas Musavi for stimulating this link. Permission to work around Dudwa National Park was granted by Mr M.C. Ghildiyal, Chief Wildlife Warden of Uttar Pradesh and Mr D.N. Suman, Director of Dudwa National Park. We gladly acknowledge the help of the park staff in a variety of ways during the course of the project. Funding was provided by the International Trust for Nature Conservation, People's Trust for Endangered Species, Oriental Bird Club, British Airways Assisting Nature Conservation and the World Pheasant Association. We thank The Open University and Aligarh Muslim University for facilities. The IUCN-SSC/BirdLife/WPA Partridge, Quail and Francolin Specialist Group provided helpful comments during the study and Drs Simon Dowell, Peter Garson and Hem Sagar Baral considerably improved the manuscript.

\section{References}

Aebischer, N. J., Robertson, P. A. and Kenward, R. E. (1993) Compositional analysis of habitat use from radio-tracking data. Ecology 74: 1313-1325.

Ali, S. and Ripley, S. D. (1983) Handbook of the birds of India and Pakistan. Compact edition. New Delhi, India: Oxford University Press.

Anon. (1990) Status and ecology of the Lesser and Bengal floricans: final report. Mumbai, India: Bombay Natural History Society.

BirdLife International (2000) Threatened birds of the world. Barcelona and Cambridge, U.K.: Lynx Edicions, and BirdLife International.

Dahal, B.R. (2001) Status and conservation of swamp francolin Francolinus gularis in Koshi Tappu Wildlife Reserve, Nepal: a preliminary study. Pp. 134-137 in M. Woodburn, P. McGowan, J. Carroll, A. Musavi and Zhang Zheng-wang, eds. Galliformes 2000. Kathmandu, Nepal: King Mahendra Trust for Nature Conservation.

Fuller, R.A., Carroll, J.P. and McGowan, P.J.K. (2000) Partridges, quails, francolins, snowcocks, guineafowl and turkeys: status survey and conservation action plan 2000-2004. Gland, Switzerland and Cambridge, U.K.: IUCN, and Reading, U.K.: World Pheasant Association.

Hilton-Taylor, C., compiler (2000) 2000 IUCN Red List. Gland, Switzerland and Cambridge, U.K.: IUCN.

Javed, S., Qureshi, Q. and Rahmani, A.R. (1999) Conservation status and distribution of Swamp Francolin in India. J. Bombay Nat. Hist. Soc. 96: 16-23.

Kalsi, R., Shakya, S. Shrestha, A.K. Javed, S. Baral, H.S. Kaul, R., McGowan, P.J.K. and Carroll, J.P. (2001) Conservation review of the Swamp Francolin in India and Nepal. Pp. 242-247 in M. Woodburn, P. McGowan, J. Carroll, A. Musavi and Zhang Zhengwang, eds. Galliformes 200o. Kathmandu, Nepal: King Mahendra Trust for Nature Conservation.

McGowan, P.J.K., Dowell, S.D., Carroll, J.P. and Aebischer, N.J. (1995) Partridges, quails, francolins, snowcocks and guineafowl: status survey and conservation action plan 1995-1999. Gland, Switzerland and Cambridge, U.K.: IUCN - The World Conservation Union.

McGowan, P.J.K., Javed, S. and Rahmani, A.R. (1996) Swamp Francolin Francolinus gularis survey technique: a case study from northern India. Forktail 11: 101-110.

Rahmani, A.R., Narayan, G. Rosalind, L., Sankaran, R. and Ganguli-Lachungpa, U. (1991) Status of the Bengal florican Houbaropsis bengalensis in India. J. Bombay Nat. Hist. Soc. 88: $349-375$. 
Shakya, S. Shrestha, A and Kalsi, R.S. (2001) Distribution of Swamp Francolin Francolinus gularis in the terai grasslands of Nepal. Pp. 126-133 in M. Woodburn, P. McGowan, J. Carroll, A. Musavi and Zhang Zheng-wang, eds. Galliformes 20oo. Kathmandu, Nepal: King Mahendra Trust for Nature Conservation.

Salafsky, N., Margoulis, R. and Redford, K. (2001) Adaptive management: a tool for conservation practitioners. Washington, D.C.: Biodiversity Support Program. Available at $<$ www.bsponline.org $>$

Walters, C.J. (1986) Adaptive management of natural resources. New York: MacMillan.

PERWEZ IQUBAL

Centre of Wildlife and Ornithology, Aligarh Muslim University, Aligarh 202 002, Uttar Pradesh, India.

\section{PHILIP J.K. MCGOWAN ${ }^{1}$}

Biology Department, The Open University, Walton Hall, Milton Keynes Mk7 6AA, UK. Current address: World Pheasant Association, 7-9 Shaftesbury Street, Fordingbridge, Hampshire SP6 IJF, U.K. E-mail: conservation@pheasant.org.uk

JOHN P. CARROLL

Daniel B. Warnell School of Forest Resources, University of Georgia, Athens, GA 30602-2152, U.S.A.

ASAD R. RAHMANI

Centre of Wildlife and Ornithology, Aligarh Muslim University, Aligarh 202 002, Uttar Pradesh, India. Current address: Bombay Natural History Society, Hornbill House, Dr Salim Ali Chowk, Shaheed Bhagat Singh Road, Bombay 400023 , India.

${ }^{1}$ Author for correspondence.

Received 12 December 2001; revision accepted 8 January 2003 